\title{
Estimation of the Wake Caused by Wind Turbine and Complex Terrain by CFD Wind Farm Modelling
}

\author{
Ko, Kyung-Nam* Huh, Jong-Chul**
}

*Test \& Evaluation Research Center for Clean Energy Development, Jeju National University(gnkor2@cheju.ac.kr),

**Mechanical Engineering Department, Jeju National University(jchuh@cheju.ac.kr)

\section{풍력단지 CFD 모델링에 의한 풍력발전기 및 복잡지형으로 인한 후류 예측}

고경남*, 허종철**

\author{
*제주대학교 청정에너지실증연구센터(gnkor2@cheju.ac.kr), \\ **제주대학교 기계공학과(jchuh@cheju.ac.kr)
}

\begin{abstract}
복잡지형에서의 풍력단지 CFD 모델링을 통한 시뮬레이션 결과가 이 논문에 주어졌다. 이 연구를 위하여 작은 산(오 름)들로 둘러싸인 제주도 성산 풍력단지가 선택되었고, 두 개의 주풍향에 대하여 ANSYS CFX로 시뮬레이션 하였다. 격자생성을 위하여 실제 지형데이터가 사용되었고, 풍력발전기와 복잡지형으로부터 발생하는 후류효과를 예측하기 위 하여 SST 난류모델 및 액추에이터 디스크 모델이 적용되었다. 그 결과, 성산 풍력단지 주변에 있는 작은 산 및 풍력발 전기에서 발생하는 후류의 영향은 $3 \sim 7 \mathrm{~km}$ 계속된다고 예측되었다. 또한 그 후류는 풍속 및 난류강도에 상당한 영향 을 미치고 있다고 예측되었다.
\end{abstract}

Keywords : 바람 에너지(Wind energy), 풍력단지(Wind farm), 전산유체역학(CFD), 후류(Wake)

\section{NOMENCLATURE}

$\begin{array}{llll}\mathrm{u} & : \text { wind velocity profile }(\mathrm{m} / \mathrm{s}) & \omega & : \text { eddy frequency }\left(\mathrm{s}^{-1}\right) \\ \mathrm{u}_{*} & : \text { friction velocity }(\mathrm{m} / \mathrm{s}) & \varepsilon & : \text { eddy dissipation }\left(\mathrm{m}^{2} / \mathrm{s}^{3}\right) \\ \kappa & : \text { Von Karman constant } & \mathrm{V} & : \text { wind speed }(\mathrm{m} / \mathrm{s}) \\ \mathrm{Z}_{0} & : \text { aerodynamic roughness length }(\mathrm{m}) & \mathrm{V}_{\text {ref }} & : \text { reference velocity }(\mathrm{m} / \mathrm{s}) \\ \mathrm{Z} & : \text { height above ground level }(\mathrm{m}) & k & : \text { turbulence kinetic energy }\left(\mathrm{m}^{2} / \mathrm{s}^{2}\right) \\ \mathrm{C}_{\mu} & : \text { standard model constant } & & \end{array}$

투고일자 : 2011년 6월 28일, 심사일자: 2011년 7월 5일, 게재확정일자 : 2011년 9월 15일

교신저자 : 고경남(gnkor2@cheju.ac.kr) 


\section{Introduction}

Wind energy technology is one of the fastest growing technologies in new and renewable energy. Average annual installed wind power capacity was $27.8 \%$ over the past five years. Wind power is estimated to provide $1.92 \%$ of the world's electricity in 2011, and to be able to meet $9.1 \%$ of the world's electricity demands by 2020. ${ }^{[1]}$

In Europe, where wind energy technology is leading the way in the world, a simple WAsP model was developed for micrositing in a prospective wind farm, and now many researchers and wind farm developers are using the WAsP model for estimating the power production of a potential site, and finding better positions for each wind turbine to obtain greater power production in many countries, including South Korea. However as the terrain in South Korea is considered complex, it might be a problem to apply the WAsP model to most types of terrain in South Korea. This is because the simpler rapid models such as in WAsP have difficulties in accurately estimating wind speed, turbulence intensity, even electric power production on complex terrain. If there are many wind turbines in a wind farm, it is more difficult to predict these variables due to wind turbines' downstream wake.

To estimate wind characteristics over complex terrain and behind wind turbines more accurately, analyses using Computational Fluid Dynamics (CFD) have been made rather than those using a WAsP model. ${ }^{[2-5]}$ In South Korea, however, there have not been many investigations using CFD techniques to apply to wind farm design over complex terrain.

As a first step to applying CFD technique to complex terrain in Jeju Island, South Korea, this present study aims to predict wind speed and turbulence intensity using ANSYS CFX software at the Seongsan wind farm on Jeju Island which is considered to have been set up on complex terrain.

\section{Site description}

The location of the Seongsan wind farm on Jeju Island is shown in Fig. 1. The Seongsan wind farm is located in eastern inland part of Jeju Island. As shown in the figure, there are some hills, which are called 'Oreum' by local people, around the wind farm. Because of the hills, the Seongsan wind farm is considered to be set within complex terrain. At present, the wind farm has ten wind turbines. It used to have six wind turbines before the summer of 2010, with which this investigation was performed as the first step to applying CFD technique to a real wind farm. The type of the six wind turbines was VESTAS V80-2.0MW with hub height of $78 \mathrm{~m}$.

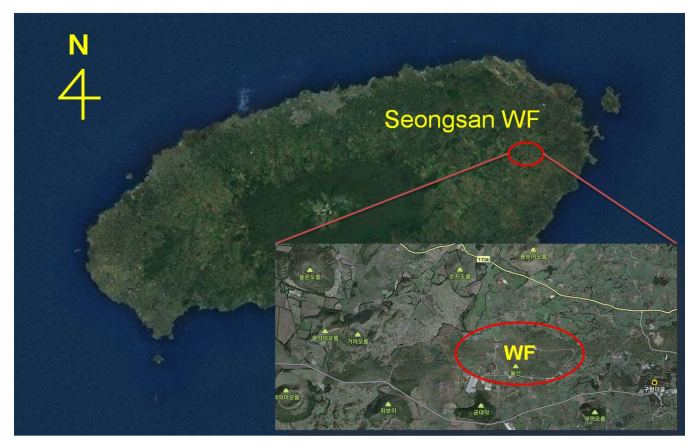

Fig. 1 Location of Seongsan wind farm on Jeju Island

Fig 2. shows wind rose at Sinsan meteorological observatory, which is about $7 \mathrm{~km}$ south of Seongsan wind farm. Two prevailing wind 
directions are from the west-north-west (300 deg.) and the west (270 deg.), which were considered as directions to analyze for this study. The wind speed of $12 \mathrm{~m} / \mathrm{s}$ at $60 \mathrm{~m}$ above ground level, used as the reference wind speed, was input as the inlet condition because it was expected to result in obtaining clear effect of the wakes behind wind turbines and hills.

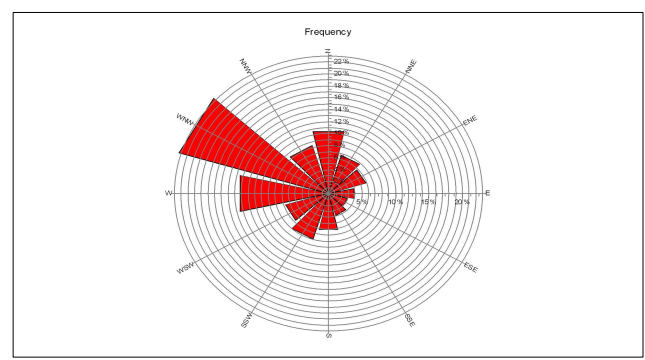

Fig. 2 Wind rose at Sinsan, which is about $7 \mathrm{~km}$ south of Seongsan wind farm

The triangulation algorithm ${ }^{[6]}$ was implemented to create terrain representation based on real terrain data on and around the Seongsan wind farm. To create the mesh, $12,000 \mathrm{~m}$ of radius and $1,000 \mathrm{~m}$ of height were given, and horizontal and vertical grid resolution were $30 \mathrm{~m}$, respectively. To obtain more accurate simulated value, $7 \mathrm{~m}$ and $7 \mathrm{~m}$ were given for the first and the second vertical layer thicknesses. The vertical expansion factor was 1.3.

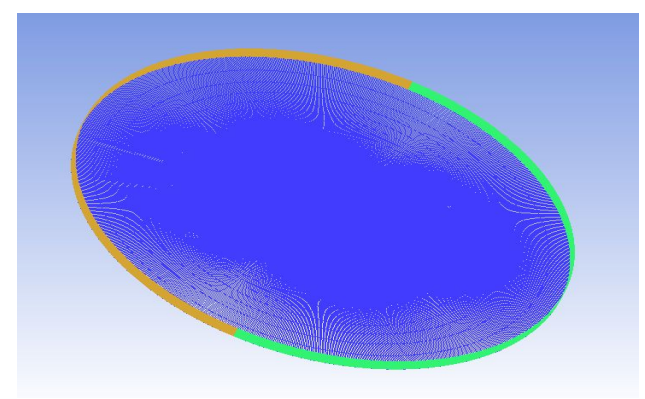

Fig. 3 Mesh for computing wind characteristics distribution in Seongsan wind farm
Though there was a little difference between the real hub height and the grid height, it was ignored because the error due to that was expected to be small. Then the surface mesh was projected onto the terrain representation. The final nodes and elements were 6,194,154 and 6,636,409 for 300 deg. of wind direction, and 4,639,679 and 4,725,857 for $270 \mathrm{deg}$. of wind direction, respectively. Also, the aerodynamic roughness was set to $0.03 \mathrm{~m}$ which corresponds to roughness class 1 . The mesh for computing wind characteristics distribution in Seongsan wind farm is shown in Fig. 3.

\section{Physical models}

The flow was computed using the Reynolds Averaged Navier Stokes equations implemented in ANSYS CFX 12.1. Shear Stress Transport (SST) $k-\omega$ turbulence model was used in this study. The inflow boundary conditions were input using profiles as follows:

$$
\begin{aligned}
& u(z)=\frac{u_{*}}{\kappa} \ln \left(\frac{z}{z_{0}}\right) \\
& k=\frac{u_{*}^{2}}{C_{\mu}^{1 / 2}} \\
& \varepsilon(z)=\frac{u_{*}^{3}}{\kappa\left(z+z_{0}\right)}
\end{aligned}
$$

where the friction velocity $\mathrm{u}_{*}$ is a prescribed reference velocity at a reference height. $\kappa$ is the Von Karman constant. $z_{0}$ and $z$ are the aerodynamic roughness length and the height above ground level, respectively. $\mathrm{C}_{\mu}$ is a standard model constant with a value 
of 0.09 . The eddy frequency $\omega$ can be obtained in ANSYS CFX based on equation (3).

To provide a practical model for calculations with many wind turbines, an actuator disk model $^{[7]}$ was used in this study. Each wind turbine was represented by momentum sink that has constant thrust per volume at disk location. So wind turbine thrust curve is needed to compute the wake effect.

\section{Simulation results}

Normalized velocity, $\mathrm{V}_{\text {normalized, }}$ and turbulence intensity, TI, were computed throughout the domain, which are expressed by:

$$
\begin{gathered}
V_{\text {normalized }}=\frac{V}{V_{\text {ref }}} \\
T I=\frac{\sqrt{\frac{2}{3} k}}{V}
\end{gathered}
$$

where $\mathrm{V}$ is the wind speed at a location, and $\mathrm{V}_{\text {ref }}$ reference velocity. $k$ is the turbulence kinetic energy.

Fig. 4 shows normalized velocity distribution at hub height under wind direction of 300 deg. The locations of wind turbines are illustrated by $(+)$, and the wind turbine numbers are also presented in the figure. First of all, the locations of hills are identified comparatively well in the figure. The wakes behind some hills extend over several kilometers, which hardly affect wind turbines in the wind farm. Although there are some hills upwind of number 4, 5 and 6 wind turbines, they scarcely affect the wind turbines because of the low height of the hills.

The wake from some of the wind turbines have a direct effect on other wind turbines. In particular, number 2 wind turbine is considered to be strongly affected by the wake downwind of the number 4 wind turbine.

Turbulence intensity distribution at hub height under wind direction of 300 deg. is shown in Fig. 5. Overall as wind speed is high at any particular region, turbulence intensity is low at that region.

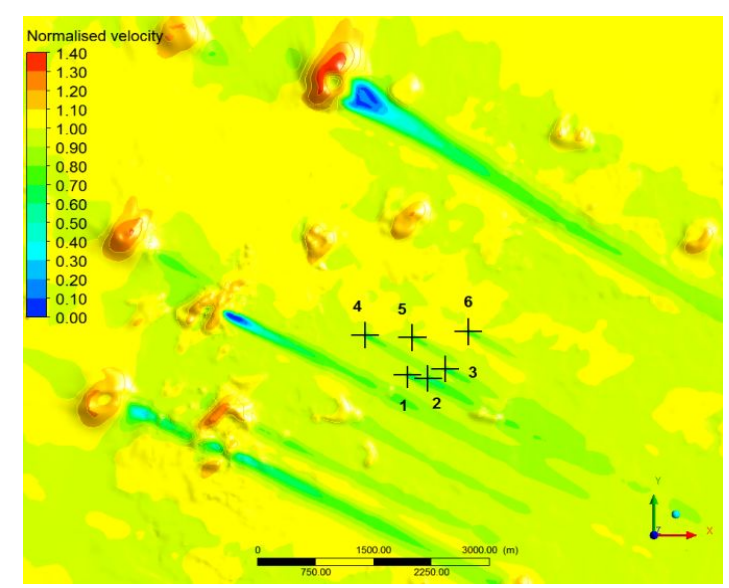

Fig. 4 Normalized velocity distribution at hub height above ground level under wind direction of 300 deg.

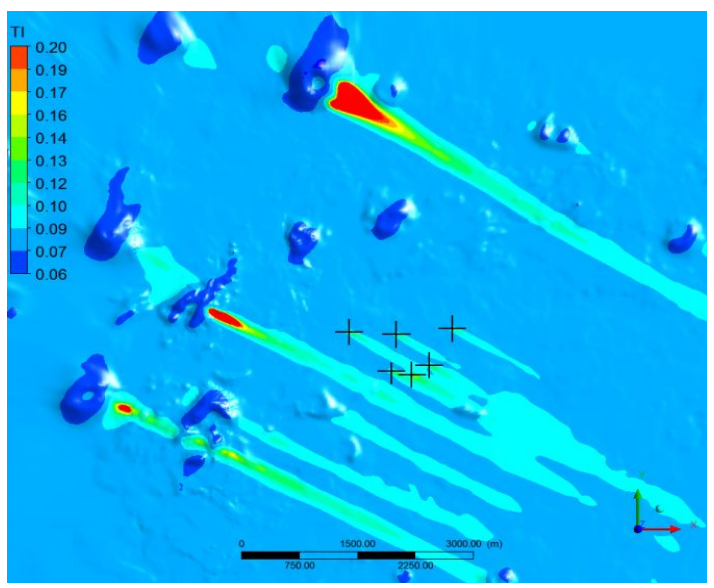

Fig. 5 Turbulence intensity distribution at hub height above ground level under wind direction of $300 \mathrm{deg}$.

한국태양에너지학회 논문집 Vol. 31, No. 5, 2011 
Strong turbulence intensity is found downwind of some hills. The cumulative effect of the wake was created downwind of number 1 , 2 and 3 wind turbines because the wind turbines were close to each other, and furthermore number 4 wind turbine existed upwind of the three wind turbines.

Fig. 6 shows vertical normalized velocity profiles at the position of each wind turbine. The zAGL in the figure means height above ground level. Due to the effect of actuator disk model which is applied between $38 \mathrm{~m}$ and $118 \mathrm{~m}$ above ground level, momentum losses are obviously identified at that position. The number 2 wind turbine had the lowest wind speed of all the turbines because it was affected the most by the wake. On the other hand, the number 6 wind turbine had the highest wind speed because it was hardly affected by the wake.

Fig. 7 represents vertical turbulence intensity profiles at the position of each wind turbine. The trend is opposite to that of normalized velocity. The number 6 wind turbine which had the lowest turbulence intensity in all the turbines, had about 9.3\% of turbulence intensity at hub height of $78 \mathrm{~m}$. The highest turbulence intensity occurred at the number 2 wind turbine, whose value was about $10.8 \%$ at hub height.

For 270 deg. which was the second prevailing wind direction, normalized velocity distribution is displayed in Fig. 8. The velocity deficit and its dissipation downwind of the wind turbines and some hills are clearly observed. The number 2 and 3 wind turbines were affected by the wake behind number 1 wind turbine, and the number 5 and 6 wind turbines were affected by the wake behind number 4 wind turbine. In particular, number 1 wind turbine is within the wake downwind of hills, which means velocity deficit occurs in the region.

Fig. 9 shows turbulence intensity distribution at hub height under wind direction of 270 deg. Due to the effect of hills and wind turbines upwind of another wind turbine, turbulence intensity became higher than normal and persisted for about $3 \sim 7 \mathrm{~km}$.

Vertical normalized velocitiy profiles at the position of each wind turbine under wind direction of $270 \mathrm{deg}$. are shown in Fig. 10. Overall wind speeds in the figure are lower than those in Fig. 6 which represents wind speeds under wind direction of 300 deg. The highest wind speed occurred at number 4 wind turbine because there were no hills and wind turbines upwind of itself. On the other hand, number 2 wind turbine had the lowest wind speed of all the turbines because of the cumulative effect of the wakes downwind of the number 1 wind turbine and hills creating an overall wake.

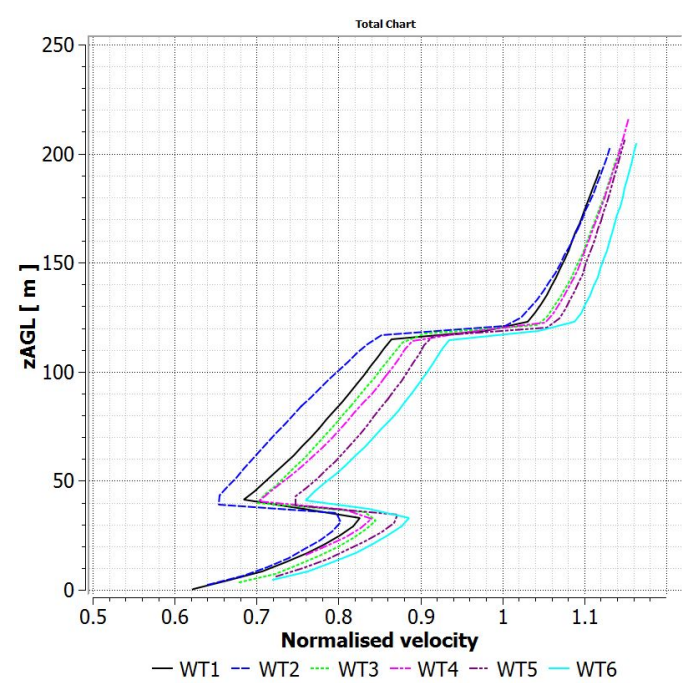

Fig. 6 Vertical normalized velocity profiles at the position of each wind turbine 


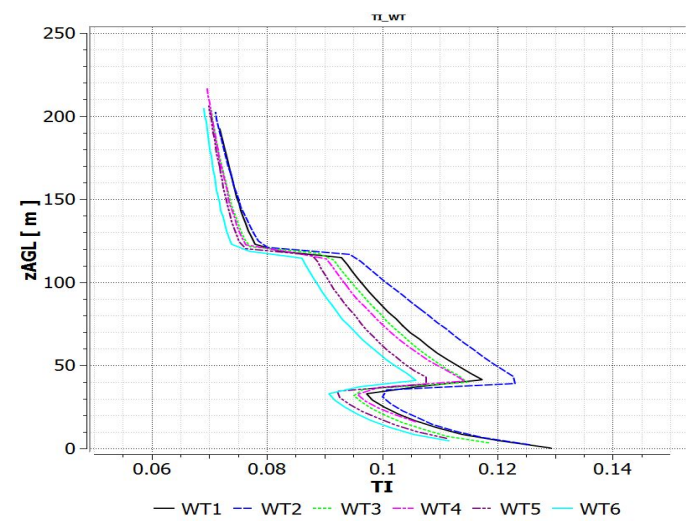

Fig. 7 Vertical turbulence intensity profiles at the position of each wind turbine

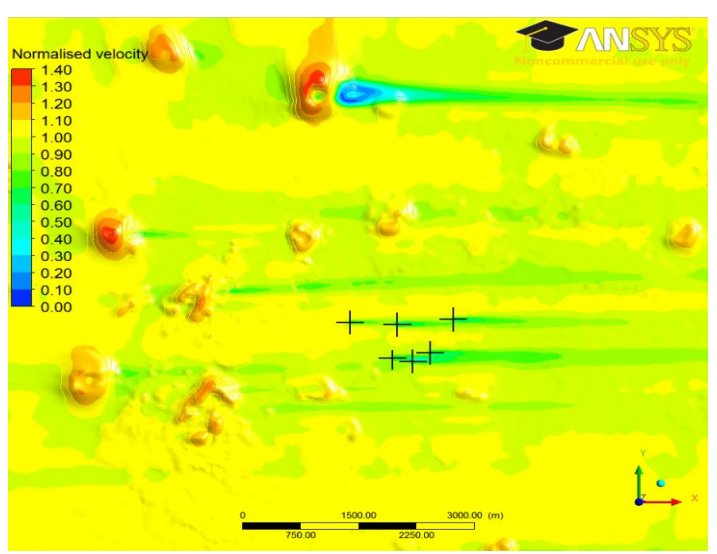

Fig. 8 Normalized velocity distribution at hub height above ground level under wind direction of 270 deg.

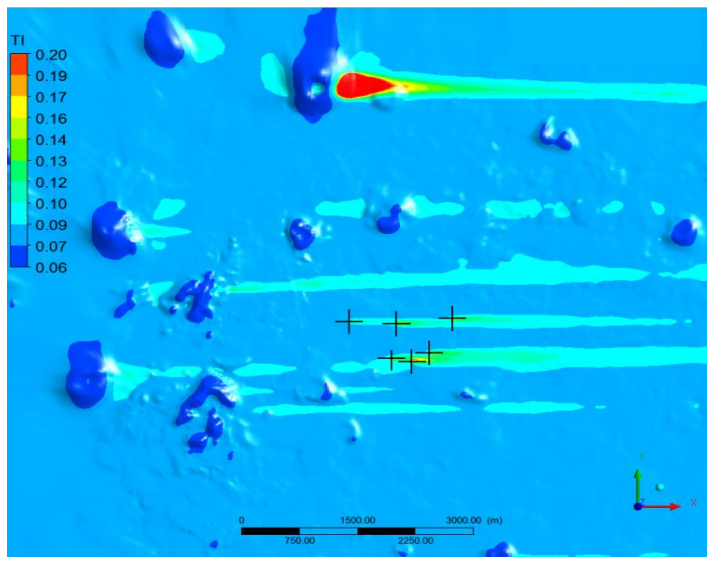

Fig. 9 Turbulence intensity distribution at hub height above ground level under wind direction of 270 deg.
Fig. 11 shows vertical turbulence intensity profiles at the position of each wind turbine under wind direction of $270 \mathrm{deg}$. Overall turbulence intensities are higher than those in Fig. 7. Turbulence intensity of the number 2 wind turbine was shown to be the strongest in the figure, while the number 4 wind turbine had the weakest turbulence intensity. The reason is the same as that shown in Fig. 10.



Fig. 10 Vertical normalized velocity profiles at the position of each wind turbine under wind direction of $270 \mathrm{deg}$.

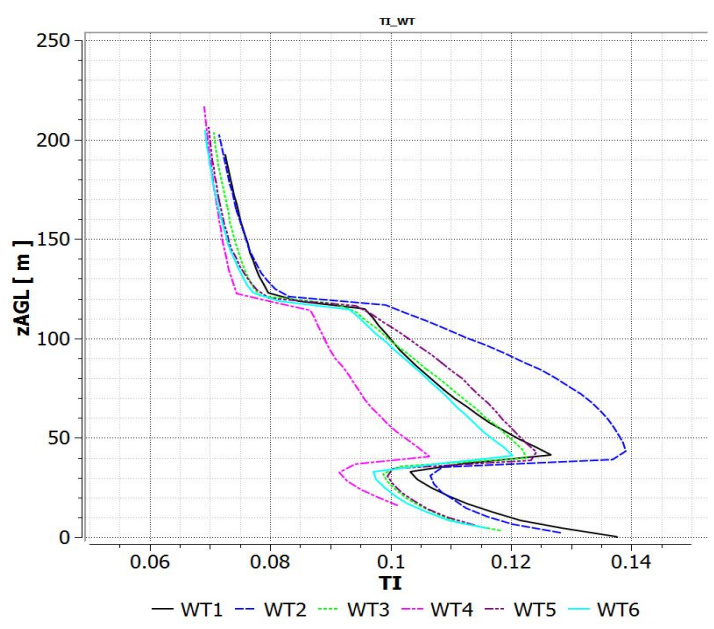

Fig. 11 Vertical turbulence intensity profiles at the position of each wind turbine under wind direction of $270 \mathrm{deg}$. 
For the number 2 wind turbine which had the strongest turbulence intensity and the lowest wind speed under wind direction of 270 deg., normalized velocity distribution in a vertical plane was examined. The result is shown in Fig. 12. The number 2 wind turbine is illustrated as a black symbol $(+)$ and is located between number 1 and number 3 wind turbine, whose locations are denoted by one horizontal black line, respectively. The wake distribution behind number 2 wind turbine is obviously identified. Where the lines of the $(+)$ intersect, this denotes the hub of wind turbine. A very low wind speed region exists under hub height just behind the wind turbine, which persists for about $150 \mathrm{~m}$. The wake becomes weaker and weaker the further it gets from the wind turbine.

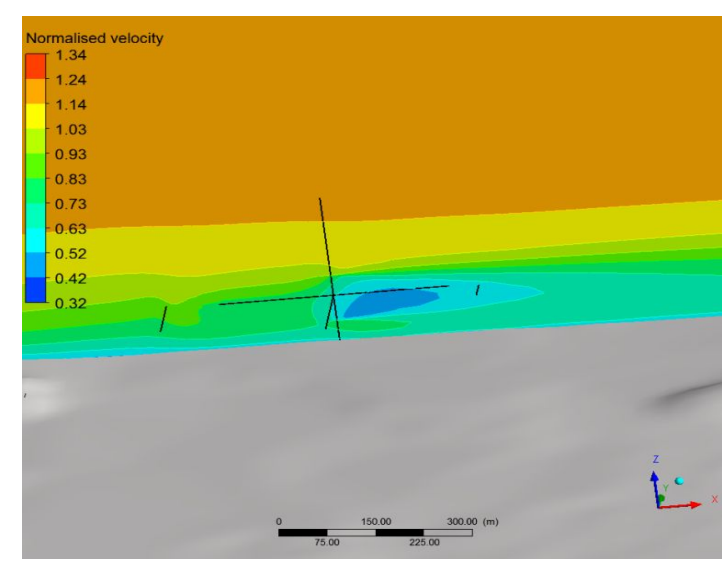

Fig. 12 Normalized velocity distribution in a vertical plane at number 2 wind turbine under wind direction of 270 deg.

Fig. 13 shows turbulence intensity distribution in a vertical plane at number 2 wind turbine under wind direction of $270 \mathrm{deg}$. Turbulence intensity distribution is similar to normalized velocity distribution in Fig. 12, and the values have opposite trends to each other.

\section{Conclusions}

Using ANSYS CFX software, the effect of complex terrain and the wake behind wind turbines was investigated for Seongsan wind farm of Jeju Island. The results are as follows.

1. The wakes downwind of hills and wind turbines are estimated to result in wind velocity deficit and enhanced turbulence intensity.

2. The hills around Seongsan wind farm are estimated to cause significant wake which persists for about $3 \sim 7 \mathrm{~km}$.

3. It is necessary that the wake model in this study should be validated under the terrain of South Korea.

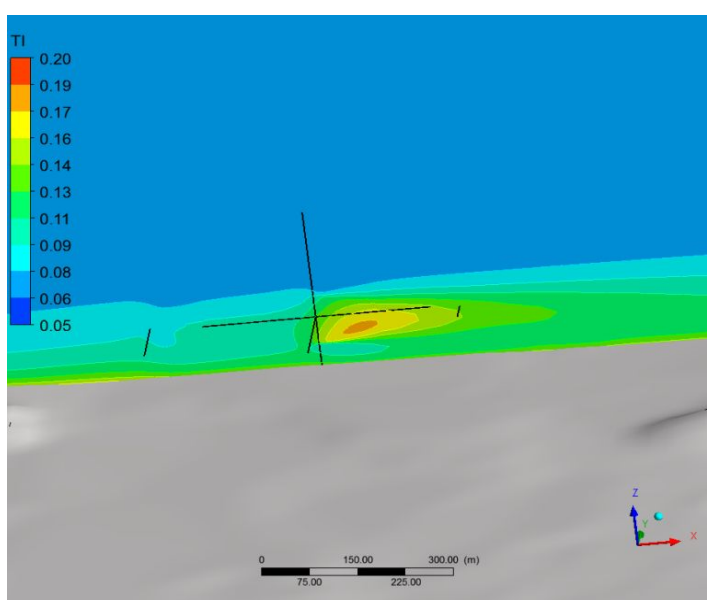

Fig. 13 Turbulence intensity distribution in a vertical plane at number 2 wind turbine under wind direction of 270 deg.

\section{References}

1. BTM Consult ApS, http://www.btm.dk, Accessed 26 June 2011.

2. Christiane Montavon et al., Practical 
issue in the use of CFD for modeling wind farms, EWEC Proceedings, 2009.

3. J. M. Prospathopoulos et al., CFD modeling of wind farms in flat and complex terrain, EWEC Proceedings, 2010.

4. D. Cabezon, K. S. Hansen, R. J. Barthelmie, Analysis and Validation of CFD Wind Farm Models in Complex Terrain. Effects Induced by Topography and Wind Turbines, EWEC Proceedings, 2010.

5. S. J. Wylie, S. Watson, A Computational Fluid Dynamics (CFD) Study of Wind Flow around a Model Forest: Comparison of Different Turbulent Closure Schemes and Varying Leaf Area Density, EWEC Proceedings, 2011.

6. S. W. Sloan, A fast algorithm for constructing Delaunay triangulations in the plane, Advances in Engineering Software, Vol. 9, pp. 34-55, 1987.

7. J. F. Manwell, J,G, McGowan A.L. Rogers, Wind Energy Explained, John Wiley \& Sons Ltd, 2004. 